Dr DALIBOR VELOJIĆ, naučni saradnik

Institut za srpsku kulturu

Priština-Leposavić, Republika Srbija

d.velojic@yahoo.com

UDK 358.2(497.1)"1918/1941"

originalan naučni rad / original scientific paper

primljeno / received: 23. 10. 2020.

prihvaćeno / accepted: 19. 5. 2021.

https://doi.org/10.29362/ist20veka.2021.2.vel.279-294

\title{
INŽINJERIJSKE JEDINICE U VOJSCI KRALJEVINE SHS/JUGOSLAVIJE 1918-1941.
}

APSTRAKT: $U$ članku se, na osnovu arhivske građe i relevantne literature, razmatra organizacija, formacija i delovanje jedinica roda inžinjerije $u$ jugoslovenskoj vojsci u periodu 1918-1941. godine, tačnije do početka Aprilskog rata. Reč je o tehničkom rodu vojske koji je za obezbeđenje borbenih dejstava koristio savremena dostignuća nauke i tehnike u meri koja je bila dostupna tadašnjoj vojsci. Kroz inžinjerijske radove i obuku regruta može se posmatrati i jedan od aspekata uloge vojske u modernizaciji društva.

KLJUČNE REČI: Vojska Kraljevine SHS/Jugoslavije, inžinjerija, pioniri, pontoniri, inžinjerijski radovi

Inžinjerija predstavlja rod vojske koji je tokom vekova, korišćenjem dostignuća nauke i tehnike, izvodio radove kako bi obezbedio borbena dejstva glavnih snaga (pešadije, konjice). Opus inžinjerijskih radova protezao se od zaprečavanja (na različite načine), preko savlađivanja prepreka (suvozemnih i vodenih), izrade i opravke komunikacija, izgradnje tvrđava, do prečišćavanja vode i maskiranja. S obzirom na raznovrsnost radova, inžinjerija je u svom sastavu imala vojnike raznih specijalnosti, bilo zanatlija drvodelja, građevinara, tesara i kovača u starom veku, bilo obučenih pionira i pontonira, a u novije doba i železničkih jedinica. Pojedine tehničke specijalnosti usled svoje malobrojnosti i nemogućnosti da formiraju samostalan rod kao što su balonske, telegrafske i jedinice golubije pošte, u mnogim armijama krajem 19. i početkom 20. veka ulazile su u sastav inžinjerije. ${ }^{1}$

U svakom slučaju, inžinjerijske jedinice nastojale su da najnovija naučno-tehnička dostignuća iskoriste kao sredstva u izvođenju radova kako bi se na što brži i kvalitetniji način i uz što manje gubitaka mogle izvoditi vojne operacije. Pored toga, inžinjerijski radovi su jedan od domena uticaja vojske u modernizaciji društva, ako se imaju u vidu izgradnja trajnijih objekata i saobraćajnica koji bi kasnije poslužili u civilne svrhe, kao i osposobljavanje stručnog kadra širokog opsega delatnosti i temeljna obuka regruta.

\footnotetext{
${ }^{1}$ Borivoje Rockov, „Inžinjerija“, Vojna enciklopedija, 3 (Beograd: Vojnoizdavački zavod, 1972), 625.
} 
U srpskoj vojsci, nakon sticanja nezavisnosti, u okviru trupa stajaće vojske pionirski i pontonirski bataljon, svaki sa po tri čete, činili su inžinjerijski puk, sa štabom u Beogradu, a zatim u Nišu. ${ }^{2}$ Uz to, u okviru Ministarstva vojnog, osnovan je inžinjerijski komitet koji se bavio rešavanjem tehničkih pitanja. U domen njegovog rada spadali su inžinjerijsko uređenje gradova, utvrđivanje položaja za odbranu, saobraćaj, a naročito uređenje i naoružanje inžinjerijskih trupa i izrada pravila i propisa koji bi se primenjivali prilikom školovanja kadrova. ${ }^{3}$ Prema formaciji iz 1889. godine stalni kadar inžinjerije sastojao se od 1. inžinjerijskog bataljona sa pet četa pionira, 2. inžinjerijskog bataljona sa železničkom, minerskom i telegrafskom četom i pontonirskog polubataljona od dve čete. ${ }^{4}$ U slučaju mobilizacije predviđeno je spajanje stalnog kadra sa njegovom rezervom, tako da je planirano formiranje inžinjerije od pet divizijskih pionirskih četa, jednog rezervnog pionirskog bataljona, jednog železničkog bataljona, jedne minerske čete, dva mostovna trena, pet divizijskih mostovnih polutrenova, dva telegrafska odeljenja, pet divizijskih telegrafsko-signalnih odeljenja i pet divizijskih alatnih kolona. ${ }^{5}$ Ovo je značilo da bi u slučaju rata svaka divizija prvog poziva bila popunjena potrebnim brojem inžinjerijskog kadra i potrebnom količinom opreme, koje nije bilo u dovoljnoj meri, tako da je formacija ostala samo na papiru. ${ }^{6} \mathrm{U}$ narednim godinama, formacija inžinjerije nije bitno menjana, tako da se do početka Prvog balkanskog rata inžinjerijska komanda sastojala od dva inžinjerijska bataljona i pontonirske komande. ${ }^{7}$

Ratna formacija predviđala je za prvi poziv divizijsku inžinjeriju sa pionirskim polubataljonom, pontonskim parkom, telegrafskim odeljenjem i inžinjerijskom alatnom kolonom, dok su divizije drugog poziva bile bez pontonskog parka. ${ }^{8}$ Osim toga, neposredno pod Vrhovnom komandom bili su železničko odeljenje, rezervni inžinjerijski bataljon II poziva, mostovni tren, minerski polubataljon, dva telegrafska odeljenja, radio-stanica, vazduhoplovna i reflektorska komanda. ${ }^{9}$ Prema pregledu formacije srpske vojske iz 1918. godine, u sastavu Vrhovne komande nalazili su se inžinjerijsko odeljenje, telegraf, Železnička komanda i minerska četa. U sastavu armijske inžinjerije nalazili su se telegrafsko, saobraćajno, reflektorsko odeljenje, kao i mostovni tren, dok je divizijska inžinjerija u sastavu imala pionirski bataljon i telegrafsko odeljenje. Konjička divizija je obuhvatala odeljenje konjičkih pionira i odeljenje telegrafista. ${ }^{10}$

${ }^{2}$ Славица Ратковић Костић, Европеизација српске војске 1878-1903 (Београд: Војноисторијски институт, 2007), 45.

${ }^{3}$ Исто, 63.

${ }^{4}$ Службени војни лист, 1889 (Београд: Министарство војске, 1889), 119.

${ }^{5}$ Исто, 123.

${ }^{6}$ Милић Милићевић, Реформа војске Србије 1897-1900 (Београд: Војноиздавачки завод, 2002), 47.

${ }^{7}$ Mile Bjelajac, Generali i admirali Kraljevine Jugoslavije (Beograd: Institut za noviju istoriju Srbije, 2004), 327.

${ }^{8}$ B. Rockov, n. d., 625.

${ }^{9}$ Isto; M. Bjelajac, Generali i admirali Kraljevine Jugoslavije, 328.

${ }^{10}$ Arhiv Jugoslavije (AJ), fond 74, Kraljev dvor, f. 79, 1-15. Pregled formacije srpske vojske 1918. 


\section{Organizacija i formacija u Vojsci Kraljevine SHS/Jugoslavije}

Razvoj inžinjerijskih jedinica u jugoslovenskoj vojsci, njihova organizacija i dislokacija, može se podeliti na dva perioda: prvi, do 1930. godine, kada su jedinice bile u sastavu armijskih oblasti i drugi, koji karakteriše ukrupnjavanje jedinica u cilju postizanja kvalitetnije obuke. U prvom periodu, u sastavu svake armijske oblasti nalazila se zasebna Komanda inžinjerije sa jednim pionirskim bataljonom (4 čete), jednim pontonirskim (polu)bataljonom (2 čete), po jednom telegrafskom i reflektorskom četom, odeljenjem golubije pošte i tehničkim parkom. ${ }^{11}$ Sa formiranjem inžinjerije V armijske oblasti kasnilo se zbog nedostatka opreme i obučenog ljudstva, s tim što su bili ustrojeni spiskovi ljudstva iz rezerve koje je trebalo mobilisati sa teritorija Moravske, Timočke i Šumadijske divizijske oblasti. ${ }^{12}$ Prema podacima iz 1928. godine, inžinjerijske jedinice bile su raspoređene na sledeći način: ${ }^{13}$

- Komanda inžinjerije I armijske oblasti (štab u Šapcu): 1. pionirski bataljon (Gornji Milanovac), 1. pontonirski bataljon (Šabac), telegrafska i reflektorska četa (Šabac), odeljenje golubije pošte (Petrovaradin), bežična stanica (Beograd).

- Komanda inžinjerije II armijske oblasti (Sarajevo): 2. pionirski bataljon (Sarajevo), 2. pontonirski bataljon (Brčko), telegrafska i reflektorska četa (Sarajevo).

- Komanda inžinjerije III armijske oblasti (Skoplje): 3. pionirski bataljon (Skoplje), 3. pontonirski bataljon (Veles), telegrafska, reflektorska četa i bežična stanica (Skoplje).

- Komanda inžinjerije IV armijske oblasti (Karlovac): 4. pionirski bataljon (Karlovac), 4. pontonirski bataljon (Ptuj), telegrafska i reflektorska četa (Karlovac), bežična stanica (Zagreb).

- Komanda inžinjerije V armijske oblasti (Niš): 5. pionirski bataljon (Negotin), telegrafska i reflektorska četa (Niš).

- Inžinjerijski bataljon Boke Kotorske.

- Po jedan telegrafski eskadron i odeljenje konjičkih pionira u Zagrebu i Nišu.

Navedena formacija zadržala se do 1930. godine, kada je formirana Komanda inžinjerije koja je imala pionirsku, pontonirsku, telegrafsko-tehničku i železničku komandu: ${ }^{14}$

- Pionirska komanda: 1. pionirski puk (Niš) sa bataljonima u Nišu i Negotinu, 2. pionirski puk (Karlovac) sa bataljonima u Karlovcu i Tivtu.

11 Mile Bjelajac, Vojska Kraljevine SHS/Jugoslavije 1922-1935 (Beograd: Institut za noviju istoriju Srbije, 1994), 36.

${ }^{12}$ Vojni arhiv (VA), Popisnik (P) 17, k. 131, f. 4, d. 4, 2. Naređenje ministra vojnog za formiranje delova u neposrednom sastavu V armijske oblasti str. pov. đ. br. 150, 1. februar 1926.

${ }^{13}$ VA, P 17, k. 195, f. 3, d. 21, 3, Raspored trupa na dan 1. jula 1928.

${ }^{14}$ VA, P 17, k. 159, f. 2, d 3, 2-3, Pregled rasporeda svih delova inžinjerije str. pov. br. 13, 2. januar 1932. 
- Pontonirska komanda: 1. pontonirski puk (Šabac), 2. pontonirski puk (Brčko) sa bataljonima u Brčkom i Ptuju.

- Telegrafsko-tehnička komanda (Zemun): telegrafski puk (Sarajevo) sa četama u Sarajevu i Meljinama i bežičnim bataljonom u Zemunu, tehnički puk (Skoplje) sa reflektorskim četama u Skoplju i Meljinama, minerskom četom u Sarajevu i bataljonom golubije pošte u Novom Sadu.

- Železnička komanda (Slavonski Brod): 1. železnički puk sa jedinicama u Slavonskom Brodu i Kotoru.

- Inžinjerijska četa komande Šibenika (Šibenik).

- Inžinjerijska oficirska škola (Beograd).

- Inžinjerijska podoficirska škola (Maribor).

U periodu 1932-1934. godine preformirani su neki delovi inžinjerije, tako da su ukinuti štab telegrafsko-tehničke komande, štab tehničkog puka, 2 štaba tehničkih bataljona, 5 četa tehničkog puka, 5 štabova inžinjerijskih parkova, 2 maskirne i 1 hidrotehnička četa. ${ }^{15}$ Reflektorske jedinice raspuštenog tehničkog puka ušle su u sastav novoformiranih protivavionskih pukova. ${ }^{16}$

Ovakav način organizacije pokazao se nepraktičnim sa gledišta mobilizacijskih priprema, jer su jedinice morale da deo kadrovskog ljudstva i materijala šalju u mesta u kojima se za njihove potrebe mobilišu obveznici, kao i da u svojim sedištima formiraju ratne jedinice za druge komande $\mathrm{i}$ da ih tako šalju na koncentracijsku prostoriju. Nedovoljan broj starešina i vojnika ovog roda, kao i nedostatak opreme, otežavali su prelaz sa mirnodopske na ratnu formaciju. ${ }^{17}$

Za razliku od ostalih rodova vojske inžinjerija je u svom domenu imala niz specijalnosti, što je uslovilo organizaciju i formaciju. Od svih struka ovog roda pioniri su činili najveći deo. Procenat regruta pionira u odnosu na ostale inžinjerijske jedinice iznosio je od 60 do $80 .{ }^{18}$ Zadaci ovih jedinica kretali su se od zaprečavanja, miniranja, savlađivanja prepreka, izrade komunikacija, utvrđivanja. Stoga su iskustva iz Prvog svetskog rata ukazivala na nedovoljan broj pionirskih jedinica, kako u rovovskom, tako i u manevarskom ratu. U jugoslovenskoj vojsci pionirske jedinice uglavnom su upotrebljavane na poslovima utvrđivanja granica, naročito kasnih tridesetih godina, kada je opasnost od rata bila sve izvesnija. Usled toga, kao loša strana ovih aktivnosti uvek je od strane komandi navođena nedovoljna mirnodopska obuka, a samim tim pretvaranje vojnika jedne tehničke službe u prostu radnu snagu. ${ }^{19}$ Ovakva angažovanja koja su opterećivala pionirske jedinice svakako su škodila obuci. Planirana stručna nastava obuhvatala je ne samo opštu obuku pionira, već i obuku specijalista i

${ }^{15}$ VA, P 17, k. 133, f. 1, d. 26, 6, Komanda inžinjerije - ministru vojske i mornarice pov. đ. br. 4215, 30. novembar 1934.

16 Živko Avramovski (prir.), Britanci o Kraljevini Jugoslaviji, II (Beograd-Zagreb: Arhiv Jugoslavije-Globus, 1986), 205.

17 Далибор Велојић, Војска у Нишу 1918-1941 (Лепосавић: Институт за српску културу Приштина, 2014), 129.

18 VA, P 17, k. 397, f. 13, d. 13; Службени војни лист, 1935, 355.

19 VA, P 17, k. 397, f. 7, d. 2. Pionirska komanda komandantu inžinjerije pov. br. 431, 14. april 1938. 
bila je predviđena tokom čitavog trajanja vojnog roka. Pioniri su, prema mišljenju viših inžinjerijskih oficira, morali da vladaju poznavanjem ne samo sredstava za rad već i materijala. Uz to, zadatak ovih jedinica obuhvatao je izgradnju mostova, podizanje ,najkomplikovanijih građevinskih objekata“, kakvi su oni za smeštaj i rad. ${ }^{20}$ Pored ličnog alata (ašovčića, sekira), oprema pionira obuhvatala je stolarski, zidarski, kovački alat, makare (mašina za pobijanje šipki i stupova u zemlju), pribor za topografske radove, eksploziv. ${ }^{21}$ Pioniri su takođe raspolagali gumenim čamcima za podizanje brzih mostova i forsiranje reka. Zanimljivo je da u slučaju rata nije predviđeno angažovanje pionira prilikom postavljanja minskih polja, već je to bio zadatak pešadije. ${ }^{22}$

U pionirskim pukovima predviđeno je bilo usavršavanje dopunskih specijalnosti, kao motorista, mašinista, minera i različitih tehničkih struka. Pomenute opreme i eksploziva za potrebe pionira bilo je u dovoljnim količinama. Upotreba ovih jedinica, međutim, zahtevala je veći stepen mehanizacije u cilju bržeg i efikasnijeg obezbeđenja borbenih dejstava. Pojedini oficiri zastupali su tezu da je minimum koji svaka pionirska četa u savremenoj vojsci treba da ispuni u pogledu mehanizacije dva teretna automobila, od kojih jedan sa elektroagregatom, jednu motornu makaru, jednu motornu testeru, jednu mehaničku spravu za bušenje čepova i dva elektropneumatična bušara. ${ }^{23}$ I usled nedostatka sredstava, učinjen je pomak u organizaciji, tako da su formirane i motorizovane pionirske čete, kao samostalne, specijalne jedinice, čiji je zadatak bio postavljanje i uklanjanje prepreka ispred linije fronta. ${ }^{24}$ Značaj pionirskih jedinica daleko je porastao osavremenjivanjem vojske, tako da se javila potreba za formiranjem pionirskih vodova $\mathrm{u}$ svakom pešadijskom puku, dok je formacija konjice već predviđala pionirske eskadrone u konjičkim divizijama. Sudeći prema obaveštajnim izveštajima, ovaj predlog imao je uzora u nemačkoj formaciji jurišnih pionirskih vodova koji su predstavljeni stranim vojnim izaslanicima u jesen 1940. godine. ${ }^{25} \mathrm{U}$ jugoslovenskoj vojsci ovi samostalni vodovi potčinjeni bi bili direktno komandantima pešadijskih pukova, a ljudstvo, uključujući i starešine sa završenim pionirskim kursevima, uzimalo bi se isključivo iz pešadijskih jedinica. ${ }^{26}$

U sastavu Komande inžinjerije formirana Pontonirska komanda imala je dva pontonirska puka. Zadatak pontonira odnosio se na radove na vodi, kao što su prevoženje pontonima i skelama, izrada mostova na plovnim potporama, zapreča-

\footnotetext{
${ }^{20}$ М. Ђелошевић, „Употреба пионира“, Ратник, III/1924, 72-73.

${ }^{21}$ Prema proračunu dnevne potrebe $u$ eksplozivu celokupne inžinjerije iznosile su $10 \mathrm{~kg}$, dok je u ratu predviđeno $1.000 \mathrm{~kg}$. VA, P 17, k. 397, f. 10, d. 1. Izveštaj komisije komandantu inžinjerije, 19. april 1940.

${ }^{22}$ Велимир Терзић, Југославија у Априлском рату 1941 (Титоград: Графички завод, 1963), 276.

${ }_{23}^{23}$ Павле Манојловић, „Наоружање и употреба пионира у рату“, Ратник, II/1938, 3.

${ }^{24}$ VA, P 17, k. 398, f. 22, d. 47, Komandant inžinjerije - načelniku Generalštaba pov. br. 9310/40, 26. novembar 1940.

${ }^{25}$ VA, P 17, f. 1, d. 47, Glavni generalštab - komandantu inžinjerije pov. đ. ob. br. 14585, 16. oktobar 1940.

${ }^{26}$ VA, P 17, k. 399, f. 1, d. 37, Ministarstvo vojske i mornarice - komandantu inžinjerije pov. br. 2386, 24. februar 1941 .
} 
vanje rečnog toka, uređenje prilaza na prelazima reka. Oprema pontonira podrazumevala je mostovni tren, odnosno pontonski materijal koji je u ratu opsluživala četa. Drveni pontonirski materijal bio je sistema Birago, dok su za podizanje teških mostova dužine 1.500 metara korišćeni sistemi Herbert. ${ }^{27}$ Korišćen je i francuski sistem M 1901 koji se mogao kombinovati sa sistemom Birago u mirnodopskom periodu, u slučaju kada se radovi izvode van neprijateljskih dejstava i bez vremenskog ograničenja. Za transport materijala korišćena su teretna vozila, dok je jedan deo prevožen konjskom zapregom. Modernizovanje vučnih sredstava nije predstavljalo jedini problem u ovim jedinicama. Naime, sam materijal, s obzirom na drvenu građu, usled prevoženja motornom vučom, mogao je da trpi štetu od jačih potresa koji nastaju pri brzoj vožnji. Tako se postavilo pitanje obnove čitavog pontonskog materijala, za šta još uvek nisu postojali uslovi. ${ }^{28}$ Samo prevoženje na rekama moglo se odvijati ručno, veslanjem, ili korišćenjem vanbrodskih motora, od kojih su u upotrebi u jugoslovenskoj vojsci bili Kovač i Altos. Na manevrima 1929. godine kod Šapca izračunato je da je vreme prevoženja motornim čamcima 150 metara za minut duplo kraće od veslanja. ${ }^{29}$ Uloga pontonira u savlađivanju vodenih prepreka dobila je na značaju radi što bržeg dejstva ostalih jedinica koje su prevožene. Tako je nova formacija konjice predviđala, nezavisno od pontonirske komande, formiranje pontonirskih eskadrona od dve mostovne jedinice u sastavu konjičkih divizija. ${ }^{30}$ Ovakva specifična služba zahtevala je određena znanja vojnika doneta iz civilstva. Podrazumevalo se da pontonir mora imati tehnička predznanja, pošto za 18 meseci trajanja vojnog roka nije bio u mogućnosti da savlada predviđeno gradivo. Usled nedostatka regruta, međutim, inžinjerijske jedinice su morale znatno da snize kriterijume. Kao primer navodimo pontonirsku jedinicu u kojoj je neplivača bilo dva puta više nego plivača, dok je nepismenih bilo $44 \%{ }^{31}$

Bataljon golubije pošte stacioniran je bio u Novom Sadu, tačnije na Petrovaradinu, gde su golubovi odgajani i otpremani na dresuru po golubarnicima u Nišu, Ljubljani, Kraljevici i Zemunu. ${ }^{32}$ Golubija pošta je imala efekta u slučajevima loše telefonske i telegrafske veze, ili prilikom bržeg napredovanja konjičkih i tenkovskih jedinica, kao i za upotrebu na isturenim osmatračkim tačkama. Jedina mana bila je sporost u odnosu na savremena sredstva veze, pošto je brzina leta goluba iznosila 60-90 km/čas, a sam dolet goluba 10-20 km, što je u uslovima savremenog ratovanja predstavljalo veliki nedostatak. ${ }^{33}$ Uprkos tome, ove jedinice su zadržane u mnogim evropskim zemljama, pre svega Nemačkoj, Velikoj Britaniji i Francuskoj. Za ovu struku

\footnotetext{
${ }^{27}$ В. Терзић, н. д., 276.

${ }^{28}$ Ћ. Данда, „Моторизација понтонира“, Инжињериски гласник, I/1932, 48.

${ }^{29}$ Ћ. Данда, „Опажања са маневра 1929“, Инжињериски гласник, III/1930, 155.

${ }^{30}$ VA, P 17, k. 691, f. 2, d. 37, Štab konjice - komandantu 2. konjičke divizije pov. đ. br. 6606, 29. decembar 1939.

${ }^{31}$ Војислав Павловић, „Одабирање младића за понтонире“, Инжсињериски гласник, V/1928, 79.

32 VA, P 17, k. 397, f. 8, d. 1, Plan dresure golubova dostavljen iz štaba inžinjerije načelniku generalštaba pov. br. 1568, 19. april 1939.

${ }^{33}$ Никола Аранђеловић, „Значај голубије поште и њена примена“, Ратник, VII/1922, 105.
} 
traženi su takođe regruti sa iskustvom gajenja golubova, naročito bolničari za rad sa veterinarom. ${ }^{34}$

Železničke jedinice su predstavljale specijalizovane jedinice za izgradnju, opravku, održavanje i eksploataciju železničke mreže u ratu. Upotrebljavane su u slučaju nemogućnosti civilnih vlasti da uspostave železnički saobraćaj. ${ }^{35}$ U jugoslovenskoj vojsci u okviru inžinjerijskih jedinica postojao je u miru železnički puk sa tehničkim saobraćajnim bataljonom i bataljonom žičanih železnica. ${ }^{36} \mathrm{U}$ ratu su razvijeni tehnički puk, saobraćajni puk, radnički puk, bataljon žičanih železnica i slagalište. ${ }^{37}$ Ove jedinice imale su posebnu ulogu u ratu, a naročito prilikom mobilizacije i prevoženja na zadatu prostoriju. U njihovu nadležnost spadali su opravka mostova i tunela, ali i rušenje pruga i vitalnih železničkih objekata. ${ }^{38}$ U svom sastavu železničke jedinice imale su sklapajuće železničke mostove, kao i lokomotive, vagone i izvesnu količinu kolosečnog materijala. ${ }^{39}$ Tesnu vezu ove jedinice održavale su sa državnim železnicama, tako da su vojnici po završetku tehničkih kurseva obavljali praktičan rad na železničkim stanicama. ${ }^{40}$

Jedinice veze su u periodu do 1930. godine predviđale po jednu telegrafsku četu u sastavu armijskih oblasti. Od tih četa i rezervnog sastava u ratu bi se formirale telegrafska komanda, telegrafsko-telefonska stanica Vrhovne komande, glavna mehanička radionica Vrhovne komande, kao i telegrafska odeljenja za sve armije i divizije. ${ }^{41}$ Realno stanje, međutim, govorilo je o nedovoljno obučenim regrutima, kojih nije bilo dovoljno, tako da su uzimani iz drugih rodova, pešadije i konjice, a zatim i o zastarelim sredstvima, neadekvatnim za opremanje savremene armije. Veći deo opreme nasleđen je od srpske vojske iz Prvog svetskog rata, bez mogućnosti modernizacije. Krajem tridesetih godina stekli su se uslovi za proizvodnju modernih radio-stanica u zemlji, ali do početka Aprilskog rata njihova proizvodnja nije bila dovoljna za potrebe vojske. ${ }^{42}$ Puk za vezu u Požarevcu tokom čitavog međuratnog perioda posedovao je minimalne uslove za rad, usled nedostatka adekvatnih prostorija. Pokušaje da se 1940. godine taj nedostatak reši podizanjem posebnih učionica opremljenih potrebnim uređajima i mrežama za obuku, omelo je izbijanje rata. ${ }^{43}$

\footnotetext{
${ }^{34}$ Службени војни лист, 1935, 355-356.

35 Stevan Jovanović, „Železničke jedinice“, Vojna enciklopedija, 10 (Beograd: Vojnoizdavački zavod, 1972), 739.

${ }^{36}$ VA, P 17, k. 399, f. 1, d. 20, Železnički puk - komandantu inžinjerije pov. br. 69, 21. januar 1941.

${ }^{37}$ S. Jovanović, $n$. d., 739.

38 Opširnije: Божидар Симовић, „Задаци железничких јединица у рату“, Ратник, X/1933, 65-82.

${ }^{39}$ В. Терзић, $н$. д., 276.

${ }^{40}$ VA, P 17, k. 399, f. 1, d. 20, Železnički puk - komandantu inžinjerije pov. br. 69, 21. januar 1941.

${ }^{41}$ Стојан Беговић, „Организација телеграфске службе у нашој војсци“, Ратник, VIII/1923, 34.

42 В. Терзић, $н$. .., 277.

${ }^{43}$ VA, P 17, k. 397, f. 13, d. 3, Puk za vezu - komandantu inžinjerije pov. br. 791, 1. april 1940.
} 


\section{Kadrovi i obuka}

Kako su potrebe inžinjerijskih jedinica iziskivale tehnički osposobljen komandni kadar na svim nivoima, obuka ljudstva morala se vršiti naknadno, često u samim jedinicama. ${ }^{44}$ Vojna akademija davala je budućim oficirima osnovu za kasnije usavršavanje u trupi. Cilj je, pre svega, bio stvoriti dobre komandire, vešte i samostalne u rukovođenju jedinicama. Trupne škole za inžinjerijske oficire formirane su pri komandama armijske inžinjerije, pontonirskim i telegrafskim bataljonima, železničkoj i telegrafskoj komandi. Oficirske škole pri komandama armijske inžinjerije pripremale su kadrove pionirske struke, dok su telegrafskim, reflektorskim i četama golubije pošte davale opšta inžinjerijska znanja. Sa komandantima bataljona obuku su držali neposredno komandanti armijske inžinjerije i železničke komande. ${ }^{45}$ Uredba o inžinjerijskoj oficirskoj školi predviđala je ovu ustanovu kao stalnu, a u administrativnom pogledu kao organ III stepena. Zadatak ove škole bio je uvežbavanje inžinjerijskih oficira u stručnim tehničkim i taktičkim radnjama, kao i upoznavanje oficira drugih struka sa upotrebom inžinjerije u borbi. U nadležnosti škole bilo je i izdavanje lista Inžinjerijski glasnik koji je izlazio četiri puta godišnje. U pogledu nastave škola je bila potčinjena inspektoru inžinjerije, dok se u administrativnom pogledu oslanjala na komandu divizijske oblasti na čijoj se teritoriji nalazila. ${ }^{46}$ Nastava u ovoj školi trajala je devet meseci i bila podeljena na teorijski deo (sedam meseci) i praktični (dva meseca). Školska godina počinjala je u novembru i trajala do aprila, dok je polaganje ispita bilo predviđeno u maju mesecu. ${ }^{47}$

Usled sve veće potrebe za stručnim kadrovima izveden je u 1940. godini stručni inžinjerijski kurs za 15 pitomaca 66. klase Vojne akademije u trajanju od tri meseca. Pitomci su bili podeljeni na pionirsku, pontonirsku i grupu za vezu. Usled obimnog programa stručne nastave i kratkog trajanja školovanja nije bilo moguće da se polaznici usavrše do potrebnog stepena. Stoga je odlučeno da se ovi pitomci, kasnije oficiri, doškoluju u Inžinjerijskoj školi, odnosno u puku za vezu, kada budu stupili u službu. Pionirsko-pontonirska grupa je od predmeta slušala poljsko utvrđivanje, pionirsku, pontonirsku i minersku službu dok je grupa veze usavršavala osnove elektrotehnike, Morzeovu azbuku, optičku i bežičnu telegrafiju. ${ }^{48}$

Uprkos nastojanju vojske da broj inžinjerijskih oficira poveća, primetan je deficit u ovom rodu koji nikako nije prevladan. Primera radi, od ukupno 2.870 promovisanih oficira u periodu 1929-1935. godine, inžinjerijskih je bilo $224{ }^{49}$

\footnotetext{
44 У. М. Ш., „Разматрања о начину спремања инжињерских старешина и стручним инжињерским школама“, Инжиъериски гласник, I/1934, 104.

${ }^{45}$ Служсбени војни лист, 1924, 132.

46 „Уредба о инжињеријској официрској школи“, Службени војни лист, 1928, 1386-1388.

47 Д. В. Б., „Инжињерска официрска школа“, Инжињериски гласник, I-II/1931, 199.

48 VA, P 17, k. 398, f. 1, d. 31, Koncept izrađen po naređenju ministra vojske i mornarice od 10. oktobra 1940.

${ }^{49}$ M. Bjelajac, Vojska Kraljevine SHS/Jugoslavije, 153.
} 
Izveštaj podnet ministru vojnom 1931. godine navodi da u inžinjerijskim jedinicama nedostaje $50 \%$ viših, 25\% nižih oficira, kao i 50\% podoficira: „Inžinjerija nema ni brojno kvalitativno potrebno starešinsko osoblje, ni potrebna sredstva, ni uslove za nastavu, ni kredite za stvaranje ovih uslova. Pionirske jedinice u toku same nastave rasparčane su, a pri takvom stanju postavljaju se zahtevi, koji pri sređenim prilikama za tehničke trupe ne bi bili mali ${ }^{650} \mathrm{U}$ tu svrhu je, pored školovanja aktivnih, dolazila u obzir i obuka rezervnih oficira. U školi rezervnih oficira inžinjerije nastava je trajala devet meseci, a klase su bile podeljene na pionirsko-pontonirsku, železničku i telegrafsku grupu. Pored opštih vojnih predmeta (ratna služba, nastava gađanja, čitanje karata, pravila službe, vojna higijena, vojna istorija, zakon o ustrojstvu vojske i mornarice, pešadijska egzercirna pravila itd.), kao i opštih inžinjerijskih (opšta fortifikacija, pravila pionirske, minerske, pontonirske, telegrafske, železničke službe), obaveznih za sve grupe, predavani su i stručni predmeti i to za pionirsko-pontonirsku grupu: poljska fortifikacija, konkretno gradivo za ove specijalnosti, praktičan rad u radionicama; za železničku grupu: pravila tehničke i saobraćajne službe, praktičan rad u elektromehaničarskoj radionici; za telegrafsku: pravila telegrafske i službe veze, eksplozivni motori. ${ }^{51} \mathrm{U}$ školu rezervnih oficira inžinjerije uglavnom su primani tehnički obrazovani civili, kojih nije bilo u dovoljnom broju, tako da se primer popune ovog roda može razmatrati u okviru šireg pitanja tehničke osposobljenosti i stručnosti kadra u čitavoj zemlji. Brojke su, međutim, raznovrsne i ne navode na siguran zaključak. Ilustracije radi, 1. pionirski puk iz Niša je na vežbi 1939. godine u pet pozivanih partija imao samo osam rezervnih oficira (u dve partije po četiri). ${ }^{52}$ Nasuprot tome, u 1. pontonirskom puku u Šapcu u vremenu od januara do aprila 1940. pozivane su tri partije oficira i primećeno je da su se odazvali u većem broju. U prvoj partiji od 21 pozvanog javilo se 16, u drugoj od 17 njih 15 , dok u trećoj od ukupno 27 nije bilo izostalih. ${ }^{53}$

Podoficirski kadar se dobijao iz inžinjerijske podoficirske škole smeštene prvo u Mariboru, a zatim u šabačkoj inžinjerijskoj kasarni. Po pitanju podoficira, stanje u inžinjeriji bilo je podnošljivije nego u ostalim rodovima. Očigledno da je za ovu struku, koja je davala praktična znanja, a koja su se mogla iskoristiti i u civilu, vladalo veće interesovanje. Istraživanje Mileta Bjelajca navodi da je prema izveštaju za 1934. godinu od 500 podoficira inžinjerije po formaciji nedostajao 21, što je u odnosu na druge rodove predstavljalo dobar procenat. $^{54}$ Inače se počeci školovanja inžinjerijskih podoficira vezuju za 1896. godinu, kada je škola formirana u Beogradu, a zatim premeštena u Niš. ${ }^{55}$ Po

\footnotetext{
50 Д. Велојић, Војска у Нишу 1918-1941, 133-134, citirano iz VA, P 17, k. 159, f. 1, d. 38/9.

${ }^{51}$ VA, P 17, k. 397, f. 3, d. 2, Pravilo i program za izvođenje nastave u školi za rezervne inžinjerijske oficire.

52 VA, P 17, f. 13, d. 16/2, Izveštaj komande 1. pionirskog puka o nastavi sa regrutima zimske partije 1939. godine, pov. br. 2459, 24. mart 1940.

${ }_{53}$ VA, P 17, f. 11, d. 23, Izveštaj 1. pontonirskog puka komandantu Pontonirske komande pov. br. 1184, 12. april 1940.

${ }^{54}$ M. Bjelajac, Vojska Kraljevine SHS/Jugoslavije, 178.

${ }^{55}$ С. Ратковић-Костић, н. д., 269, 373; Време, 14. 11. 1934, 8.
} 
završetku Prvog svetskog rata, škola je obnovila rad 1919. godine i primala je po 100 pitomaca u klasi, državljana Kraljevine SHS, starijih od 16 godina. Jedan od uslova za prijem bila su završena dva razreda gimnazije ili realke, ili, izuzetno za tu godinu, četiri razreda osnovne škole. ${ }^{56}$ Inžinjerijska podoficirska škola je kao administrativni organ III stepena u komandnom, nastavnom i disciplinskom pogledu bila potčinjena inspektoratu inžinjerije, dok se u pogledu snabdevanja oslanjala na divizijsku oblast na čijoj je teritoriji bila smeštena. ${ }^{57}$ Nastava u školi trajala je dve školske godine i bila podeljena u četiri tečaja. Prvi i treći tečaj bili su teorijski, trajali su od oktobra do marta, a drugi i četvrti praktični, od aprila do septembra. ${ }^{58}$ Podela na specijalnosti vršena je na osnovu uspeha, ali i završene škole u građanstvu, u trećem tečaju i to na pionirskopontonirsku, železničku i grupu za vezu. ${ }^{59} \mathrm{U}$ ostalim, uže stručnim specijalnostima podoficiri su se obučavali nakon dolaska u trupu. Kursevi su organizovani na nivou viših komandi, kao što je 1938. godine izveden radio-telegrafski kurs u organizaciji Komande mornarice u trajanju od godinu dana. ${ }^{60}$

Služenje u pojedinim specijalnostima ovog roda svakako je zahtevalo minimum predznanja regruta iz domena tehnike. Delom zbog toga, a delom i usled nedostatka opreme u jedinicama, postojao je deficit među obveznicima $\mathrm{u}$ inžinjeriji, prema podacima iz 1931. godine, oko 35.000 ljudi. Odluka da se iz konjice, gde je bilo viška obveznika, prebaci u inžinjeriju oko 2.500, ublažila bi problem. ${ }^{61}$ Komanda inžinjerije, međutim, mogla je da, u skladu sa postojećom formacijom, primi jedva polovinu od tog broja, od kojih bi dobar deo morale biti zanatlije. ${ }^{62}$ Komanda je morala imati u vidu i činjenicu da nedostatak oficira, ali i smeštajnih kapaciteta može uticati na prijem većeg broja regruta u jedinice. $U$ izveštaju Pionirske komande iz 1938. godine navodi se da obuka trpi usled nedostatka starešina. Na sugestiju komandanta inžinjerije da se nastava izvede na nivou čitavih pukova, odgovoreno je kako je to preglomazan posao i da bi deo starešina angažovanih na poslovima utvrđivanja morao biti vraćen u jedinice. ${ }^{63}$ Slična zapažanja izneta su i kod inžinjerijskog bataljona Boke Kotorske. ${ }^{64}$

56 „Конкурс за питомце инжињеријске подофицирске школе“, Службени војни лист, 1919, 885-886.

57 „Уредба о подофицирским школама у сталном кадру код главних родова војске“ Службени војни лист, 1924, 43-44.

${ }^{58}$ VA, P 17, k. 399, f. 3, d. 3, Nastavni plan i program za inžinjerijsku podoficirsku školu.

${ }^{59}$ Isto.

${ }^{60}$ VA, P 17, k. 397, f. 7, d. 8, Program radiotelegrafskog kursa za inžinjerijske podoficire u 1938. godini.

61 „Za inžinjeriju, u kojoj predstoji formiranje novih jedinica predviđeno je 7.225 regruta, t. j. manje 1.527 regruta nego što iznosi formacijsko brojno stanje prema sadašnjem razvoju inžinjerije.“ VA, P 17, k. 159, f. 1, d. 38, 1, Glavni generalštab - ministru vojske i mornarice str. pov. đ. o br. 809, 28. mart 1931.

${ }^{62}$ VA, P 17, k. 159, f. 1, d. 38, 1, Komanda inžinjerije - ministru vojske i mornarice str. pov. 551, 18. april 1931.

${ }^{63}$ VA, P 17, k. 397, f. 7, d. 2, Izveštaj Pionirske komande Komandi inžinjerije pov. br. 431, 14. april 1938.

${ }^{64}$ VA, P 17, f. 13, d. 13, Izveštaj inžinjerijskog bataljona Boke Kotorske Komandi inžinjerije pov. br. 1180,15 . april 1940 . 
U 1. pionirskom puku u Nišu nastava se usled nedostatka sredstava za uređenje poligona izvodila samo u letnjem periodu, dok su preko zime regruti učeni teoriji u kasarni. ${ }^{65}$ Kapaciteti za smeštaj ljudstva inžinjerijske kasarne 1. pionirskog puka bili su nedovoljni, tako da je i to jedan od razloga prijema manjeg broja regruta u inžinjerijske jedinice. U sanitetskom godišnjaku za 19261927. godinu navedeno je da kasarna zahteva temeljnu opravku kako spolja tako i iznutra: „U zimsko doba kubatura iznosi više od $15 \mathrm{~m}^{3}$ na vojnika, a po dolasku regruta do $9 \mathrm{~m}^{3}$... Po sobama mestimično opao malter. Prozori $i$ vrata potrebuju temeljne opravke... U kasarni postoji parno grejanje koje ne odgovara svom zadatku, jer od dva kazana radi samo jedan, a drugi u neispravnom stanju, tako da nema dosta pare za celu kasarnu. Kredit za opravku drugog kazana nije dobiven... Osvetljenje u kasarni slabo zbog preopterećenja Niške centrale... Trpezarije ne postoje, već leti vojnici ručaju u polju, a zimi po hodnicima“. ${ }^{66}$ U izveštaju Komande inžinjerije Ministarstvu vojske i mornarice 1931. godine stajalo je da inžinjerija može veći broj regruta primiti za kadrovske jedinice koje imaju uređena vežbališta. ${ }^{67}$

Obuka inžinjerijskih jedinica izvodila se u kasarnama i na terenu, u zavisnosti od specijalnosti. Budući da specijalizovanih poligona nije bilo, jedinice su se uvežbavale na postojećim garnizonim mestima sa ostalim rodovima. Primera radi, 1. pionirski puk je obuku i vežbe izvodio na aleksinačkom poligonu, ustupljenom vojnim vlastima i uređenom za obuku pionira, ali i ostalih jedinica niškog garnizona. Prvi puk je bio zadužen za radove oko nivelacije zemljišta, izgradnje puteva, bunara i baraka za smeštaj. ${ }^{68}$ Takvo stanje navelo je Komandu inžinjerije da Vrhovnoj inspekciji vojne sile uputi predlog za obrazovanje većeg inžinjerijskog poligona za obuku i vežbanje. U predlogu je jasno navedena namena poligona za uvežbavanje isključivo pionira u poljskom utvrđivanju, napadu na utvrđene položaje, savlađivanju rečnih tokova prevoženjem sa mostogradnjom, izradi komunikacija, minerskoj službi, kao i zaprečavanju. Pošto je pionirski puk u Nišu bio obezbeđen, nekoliko godina pre pisanja ovog izveštaja komanda je pokrenula pitanje obrazovanja poligona kod Karlovca za uvežbavanje 2. pionirskog puka, elektromašinskih, vodosnabdevačkih i maskirnih četa. Obrazloženje ovog predloga bilo je da pontonirskim, železničkim i jedinicama veze ovakav poligon nije neophodan. Pontonirske jedinice su inače smeštene u garnizonima blizu velikih reka, železničke se uvežbavaju u okviru sistema državnih železnica, dok za jedinice veze nije potreban poligon. Pionirske jedinice, međutim, zbog specifičnosti struke, angažovane su na poslovima utvrđivanja, tako da u poslednjih 20 godina nisu izvodile stručnu nastavu u potpunosti. Iz tog razloga stručna osposobljenost pionira više je odgovarala radničkim, a

${ }^{65}$ VA, P 17, f. 13, d. 16, Izveštaj komandanta 1. pionirskog puka o obuci u 1940. godini.

${ }^{66}$ Д. Велојић, Војска у Нишу 1918-1941, 132. Citirano iz: Војно-санитетски статистички годишњак за 1926. и 1927 (Београд: Министарство војске и морнарице, 1929), 182.

${ }^{67}$ VA, P 17, k. 159, f. 1, d. 38, Komanda inžinjerije - Ministarstvu vojske i mornarice str. pov. br. 711, 8. maj 1931.

${ }^{68}$ VA, P 17, k. 574, f. 2, d. 33/3, Projekat vežbanja inžinjerijskih jedinica na aleksinačkom poligonu. 
nikako jurišnim, obučenim inžinjerijskim jedinicama. ${ }^{69}$ Isti predlog predviđao je i formiranje inžinjerijskog školskog centra - Komande inžinjerskih škola sa sedištem u Šapcu koje bi obuhvatale inžinjerijsku oficirsku i podoficirsku školu. Za uvežbavanje školi bi bili dostupni pontonirski poligon u Šapcu, kao i poligon inžinjerijske podoficirske škole. ${ }^{70}$ Iz ovog predloga primetna je potreba za podizanje inžinjerije kao roda na viši nivo obuke, s obzirom na razvoj vojne nauke i potrebe savremene vojske za osposobljenim tehničkim jedinicama koje bi obezbeđivale dejstva pešadije, artiljerije, konjice i oklopnih vozila.

Pomak u obuci i definisanju jedinstvenog školskog centra do početka rata nije postignut, upravo zbog intenzivnijeg angažovanja tridesetih godina na poslovima utvrđivanja granica, na pomoći usled elementarnih nepogoda, redovnim radovima po garnizonima, ili na izgradnji spomenika na Avali. ${ }^{71}$ Problem nedovoljne obučenosti vojnika iznela je i Pionirska komanda dve godine ranije, odbacujući uvreženo mišljenje da su radovi na utvrđivanju vezani isključivo za inžinjerijske jedinice. Prema ovoj komandi, radovi na izradi fortifikacijskih postrojenja su jednostavni, tako da njih mogu obavljati i drugi vojnici bilo kog roda vojske. Zatim sledi da iako inžinjerijske jedinice treba da imaju najveći broj stručnih radnika, ti se radnici nalaze u ostalim rodovima vojske. U vreme rata najsloženije radove izvodili su vojnici svih rodova vojske, usled malog broja i bez pomoći inžinjerijskih trupa. Svim radovima na utvrđivanju uglavnom su rukovodili stručni nadzorni inženjeri, dok su starešine bile odgovorne za disciplinu. Iznet je predlog da se za radove upotrebe samo neophodni stručnjaci iz inžinjerije, kao i da prisustvo inžinjerijskih oficira ne prelazi $20 \%$ od ukupnog broja. ${ }^{72}$

Kada je u pitanju obuka regruta, kako je navedeno, poželjno je bilo posedovati predznanje iz građanskih škola. Prioritet kod popune inžinjerijskih jedinica imali su mladići sa završenim zanatskim, tehničkim, železničkim i saobraćajnim školama. U svakom slučaju, obuka u kadru pružala je regrutima znanje koje su mogli da iskoriste prilikom zapošljavanja, što je potvrdilo ulogu vojske u podizanju tehničke kulture stanovništva. Kada je Komanda inžinjerije 1940. godine predložila održavanje kursa za motoriste i mašiniste, predviđala je petomesečnu obuku u rukovanju motorima i mašinama. ${ }^{73}$ Slično je bilo $u$ nastavnom planu za tehničku školu motorizovanih pionirskih jedinica koji je predvideo petomesečnu obuku motorista i telefonista. ${ }^{74}$ Pontonirska komanda je

${ }^{69}$ VA, P 17, k. 398, f. 2, d. 50, Predlog Komande inžinjerije Vrhovnoj inspekciji vojne sile pov. br. 8959/940, 29. novembar 1940.

${ }^{70}$ Isto.

${ }^{71}$ Spomenik je građen u periodu 1934-1938. godine, uglavnom angažovanjem 1. pionirskog puka. Opširnije videti: Уредништво, „Израда споменика Незнаном јунаку на Авали“, Инжињериски гласник, II/1936, 119-155; III/1937, 63-95; I/1937, 88-162; Милан Недић, „Наша војска и споменик Незнаном јунаку на Авали“, Ратник, I/1939, 1-20.

${ }^{72}$ VA, P 17, k. 397, f. 7, d. 2, Pionirska komanda - komandantu inžinjerije pov. br. 431, 14. april 1938.

${ }^{73}$ VA, P 17, f. 9, d. 13, Predlog Komande inžinjerije o održavanju kursa za motoriste i mašiniste pov. br. 2566, 26. mart 1940.

${ }^{74}$ VA, P 17, f. 12 , d. 1, Nastavni plan u tehničkoj školi za obuku u motorizovanim pionirskim jedinicama. 
nakon završene tehničke škole odabrane vojnike slala na zaseban saobraćajni kurs. ${ }^{75} \mathrm{U}$ železničkom puku vojnici tehničkog bataljona prolazili su šestomesečnu stručnu obuku, dok su u saobraćajnom bataljonu, nakon završene tehničke nastave, raspoređivani na stažiranje pri državnim železnicama. ${ }^{76}$

Regrutovanjem stručnih kadrova, međutim, nije se dostigla predviđena formacija. Jedan od razloga bio je mali broj školovanih i tehnički osposobljenih mladića, što je i razumljivo ako se u obzir uzme agrarni karakter Jugoslavije, kao i ozbiljan broj nepismenog stanovništva (prema popisu iz 1931. godine i do $45 \%){ }^{77} \mathrm{U}$ ovom slučaju zadatak komandi i jedinica često se svodio na puko opismenjavanje regruta, kako bi mogli da prate i najosnovniju obuku. Analfabetske kurseve držali su mesni učitelji, ili, ukoliko nije bilo sredstava za isplatu dnevnica, sami oficiri. Uspeh u opismenjavanju zavisio je od drugih aktivnosti i uglavnom je iznosio i do $80 \% .^{78}$ Navešćemo neke primere kao ilustraciju procenta analfabeta, kao i procenta opismenjenih. U 1926. godini u 1. pontonirskom bataljonu u Šapcu bilo je 58 nepismenih, uglavnom sa teritorije Srbije. ${ }^{79}$ U 1. pionirskom puku 1938. godine nastavu su izvodili oficiri, usled nedostatka novca za honorare učiteljima. ${ }^{80}$ Prema podacima Pionirske komande iz 1939. godine od 1.075 regruta $u$ 1. i 2. pionirskom bataljonu nepismeno je bilo $5 \%$, ali nisu opismenjeni. ${ }^{81}$ Naredne godine od 1.067 regruta u 1. pionirskom puku nepismenih je bilo $29 \%$, u 2. pionirskom od 1.117 nepismenih $18 \%$ i u inžinjerijskom bataljonu Boke Kotorske od 260 nepismenih 18\%. Na kraju vojnog roka nijedan analfabeta nije opismenjen, a kao razlog navodi se nedostatak oficira, kao i materijalnih sredstava. ${ }^{82}$ Isti izvor, međutim, navodi da je u inžinjerijskoj četi u Šibeniku od 108 regruta nepismen bio 21 i da je opismenjeno $17 .{ }^{83} \mathrm{Nedo}-$ voljan broj oficira u prvom slučaju jeste predstavljao veliki problem, s obzirom na angažovanje na poslovima utvrđivanja, ali je neshvatljiv razlog nedostatak novca, pošto su sredstva odobravana na nivou Ministarstva vojske i mornarice, proporcionalno za svaki garnizon.

Početak Aprilskog rata inžinjerijske jedinice dočekale su sa zastarelom ili nedovoljnom opremom, ali i sa nedovoljno obučenim kadrom i obveznicima, što je inače bilo simptomatično za čitavu vojsku. U samom ratu od aktivnog jezgra formirane su armijska i divizijska inžinjerija. Tako je u štabovima armija postojalo mesto komandanta armijske inžinjerije, a formirani su po jedan pio-

\footnotetext{
${ }^{75}$ VA, P 17, f. 9, d. 37, Štab inžinjerije pov. br. 2737, 3. april 1940.

${ }^{76}$ VA, P 17, k. 399, f. 1, d. 20, Železnički puk - komandantu inžinjerije pov. br. 69, 21. januar 1941.

${ }^{77}$ Definitivni rezultati popisa stanovništva od 31. marta 1931, III (Beograd: Državna štamparija, 1938), 2.

78 Opširnije videti: Dalibor Velojić, „Analfabetski kursevi u Vojsci Kraljevine SHS/Jugoslavije 1918-1941“, Istorija 20. veka, br. 1, (2019), 37-52.

${ }^{79}$ AJ, fond 66, Ministarstvo prosvete Kraljevine Jugoslavije, f. 2254.

${ }^{80}$ AJ, 66-2478.

${ }^{81}$ VA, P 17, k. 397, f. 13, d. 9, Statistički podaci o pismenosti u inžinjeriji iz 1939.

82 VA, P 17, k. 397, f. 13, d. 9, Statistički podaci o pismenosti u inžinjeriji iz 1940.

${ }^{83}$ Isto.
} 
nirski i pontonirski bataljon, kao i maskirna četa. Operativne divizije u svom sastavu imale su pionirski bataljon od tri čete. ${ }^{84}$ Štabovi inžinjerije, kao i pionirski bataljoni u sastavu divizija formirani su od četa 1, 2. i 3. bataljona 1 . pionirskog puka. ${ }^{85}$

\section{Zaključak}

Uloga inžinjerije u savremenom ratu podrazumevala je korišćenje najsavremenijih dostignuća nauke i tehnike. Inžinjerijske jedinice pripremale su, obezbeđivale i olakšavale dejstva ostalih rodova, pešadije, konjice i oklopnih vozila. Kao rod sa najviše specijalnosti, inžinjerija je podrazumevala raznovrsnu obuku, kao i opremu za koju je potrebno bilo izdvojiti značajna sredstva. Za jugoslovensku vojsku izdvajanje sredstava za opremanje inžinjerijskih jedinica predstavljalo je teškoću, s obzirom na potrebe i osavremenjivanje ostalih rodova, pre svega artiljerije, oklopnih jedinica i vazduhoplovstva.

Uz to, tokom čitavog međuratnog perioda hroničan je bio nedostatak regruta adekvatno tehnički obrazovanih, koji bi nesmetano mogli da prate nastavu u trupi čitavih 18 meseci. Redovna je pojava bila da tehničke jedinice, čiji standardi u obuci pretpostavljaju određen visok nivo predznanja, moraju da izvode nastavu u opismenjavanju regruta. Česti terenski radovi, naročito na poslovima utvrđivanja granica, ometali su redovnu obuku, što je bio aktuelan problem sa kojim se Komanda inžinjerije suočavala. Kao rezultat takvog zanemarivanja obuke oslabljene su, pre svega, pionirske jedinice, kao najbrojnija specijalnost ovog roda $i$ svedene na običnu radnu snagu. Pokušaji Komande inžinjerije da jedinicama uvede redovnu obuku pokazali su se neuspešnim, s obzirom na potrebu za urgentnim radovima na osiguranju državne granice.

\footnotetext{
${ }^{84}$ В. Терзић, н. д., 266.

${ }^{85}$ VA, P 17, k. 159, f. 1, d. 39/10, Uput o izvođenju formacije u mobilno i ratno doba iz 1931.
} 


\section{REFERENCE}

- Avramovski, Živko, prir. Britanci o Kraljevini Jugoslaviji, II. BeogradZagreb: Arhiv Jugoslavije-Globus, 1986.

- Aranđelović, Nikola. „Značaj golubije pošte i njena primena“. Ratnik, VII/1922, 103-110.

- Begović, Stojan. „Organizacija telegrafske službe u našoj vojsci“. Ratnik, VIII/1923, 32-44.

- Bjelajac, Mile. Vojska Kraljevine SHS/Jugoslavije 1922-1935. Beograd: Institut za noviju istoriju Srbije, 1994.

- Bjelajac, Mile. Generali i admirali Kraljevine Jugoslavije. Beograd: Institut za noviju istoriju Srbije, 2004.

- D. V. B. ,Inžinjerska oficirska škola“. Inžinjeriski glasnik, I-II/1931, 199-215.

- Danda, Ć. „Motorizacija pontonira“. Inžinjerijski glasnik, I/1932, 45-58.

- Danda, Ć. „Opažanja sa manevra 1929“. Inžinjerijski glasnik, III/1930, 153-158.

- Definitivni rezultati popisa stanovništva od 31. marta 1931. III. Beograd: Državna štamparija, 1938.

- Đelošević, M. „Upotreba Pionira“. Ratnik, III/1924, 67-86.

- Jovanović, Stevan. „Železničke jedinice“. Vojna enciklopedija, 10. Beograd: Vojnoizdavački zavod, 1972.

- Manojlović, Pavle. „Naoružanje i upotreba pionira u ratu“. Ratnik, II/1938, 1-17.

- Milićević, Milić. Reforma vojske Srbije 1897-1900. Beograd: Vojnoizdavački zavod, 2002.

- Nedić, Milan. „Naša vojska i spomenik Neznanom junaku na Avali“, Ratnik, I/1939, 1-20.

- Pavlović, Vojislav. „Odabiranje mladića za pontonire“. Inžinjeriski glasnik, $\mathrm{V} / 1928,78-82$.

- Ratković Kostić, Slavica. Evropeizacija srpske vojske 1878-1903. Beograd: Vojnoistorijski institut, 2007.

- Rockov, Borivoje. „Inžinjerija“. Vojna enciklopedija, 3. Beograd: Vojnoizdavački zavod, 1972.

- Simović, Božidar. „Zadaci železničkih jedinica u ratu“, Ratnik, X/1933, 65-82.

- Terzić, Velimir. Jugoslavija u Aprilskom ratu 1941. Titograd: Grafički zavod, 1963.

- U. M. Š. „Razmatranja o načinu spremanja inžinjerskih starešina i stručnim inžinjerskim školama“. Inžinjeriski glasnik, I/1934, 102-133.

- Uredništvo, „Izrada spomenika Neznanom junaku na Avali“, Inžinjerijski glasnik, II/1936, 119-155; III/1937, 63-95; I/1937, 88-162.

- Velojić, Dalibor. „Analfabetski kursevi u Vojsci Kraljevine SHS/Jugoslavije 1918-1941“, Istorija 20. veka, br. 1, (2019), 37-52.

https://doi.org/10.29362/ist20veka.2019.1.vel.37-52

- Velojić, Dalibor. Vojska u Nišu 1918-1941. Leposavić: Institut za srpsku kulturu Priština, 2014.

- Vojno-sanitetski statistički godišnjak za 1926. i 1927. Beograd: Ministarstvo vojske i mornarice, 1929. 
DALIBOR VELOJIĆ, PhD, Research Associate

Institute for Serbian Culture

Priština-Leposavić, Republic of Serbia

d.velojic@yahoo.com

ENGINEER UNITS IN THE ROYAL YUGOSLAV ARMY 1918-1941

\section{Summary}

The formation of engineer units in the Royal Yugoslav Army during the 1920s and 1930s developed in two phases. The first was its engagement within the army divisions and in the second phase was the establishment of a unique engineering command, including pioneer, pontoon, and military traffic commands. Considering their different specialized activities, planned complex training demanded certain financial resources as well as an adequately qualified command staff. The lack of engineering officers and non-commissioned officers was one of the reasons why the recruits did not have regular lectures. Also, whole units were often sent out of their garrisons, especially for the purpose of strengthening the country's borders, which posed a serious problem, which was not solved during the entire interwar period. Another problem was a small number of recruits, which is why they had to be taken over from other military units, plus the fact that they were mostly technically inexperienced and frequently even illiterate. In addition, modern equipment was scarce, all of which made good quality training impossible.

KEYWORDS: Royal Yugoslav Army, Engineering, Pioneer, Pontoon Engineer, Projects 